\title{
Land Use/Cover Change analysis and its Implication on Livestock Feed Resource Availabilities in Southeastern Rangeland of Ethiopia
}

\author{
Matiwos Habte ${ }^{1}$, Mitiku Eshetu ${ }^{2}$, Abiyot Legesse ${ }^{1}$, Melese Maryo ${ }^{3}$, and Dereje Andualem ${ }^{1}$ \\ ${ }^{1}$ Dilla University \\ ${ }^{2}$ Haramaya University \\ ${ }^{3}$ Ethiopian Biodiversity Institute
}

October 1, 2020

\begin{abstract}
The objective of this study was to analyze the combined effects of climate and land use/cover changes on livestock feed resources and livestock species composition. The land use/cover data were generated from Landsat images of 1986, 1995,2010 and 2018. The images were classified using a maximum likelihood classifier algorithm. The result from meteorological data and the land use/cover change were compared with household perception on livestock feed availability and livestock species composition. The result showed that the dominant land use/cover in the eco-region throughout the study period was bush/shrub cover followed by woody vegetation. This study revealed transition of land use/cover from grassland, woody and forest vegetation cover to bush/shrub and cropland in the study areas. The analysis of time series meteorological data showed significantly increasing patterns of temperature, and the highly variable nature of rainfall during 1986-2018. The pattern of livestock population throughout the analysis period exhibited a significantly increasing trend. The land use/cover, temperature and rainfall significantly affected livestock feed availability and quality. Over the last 32 years, potential grazing resources had been declined with a resultant increase in the proportion of bush/shrub feed resources available for livestock. The inter-annual variation of rainfall during the analysis period was $40.45 \%$, which implies that the rangeland is in non-equilibrium dynamics. The rangelands carrying capacity was significantly decreased from $3.76 \mathrm{TLU} / \mathrm{ha} /$ year in 1986 to $1.74 \mathrm{TLU} / \mathrm{ha} / \mathrm{year}$ in 2018 . However, the stocking rate was increased from $1.8 \mathrm{TLU} / \mathrm{ha} /$ year in 1986 into $7.15 \mathrm{TLU} / \mathrm{ha} /$ year during 1986-2018. It is recommendable to choose camel and goat more likely than cattle and sheep raising with increasing temperature and decreasing pattern of rainfall. Hence, available feed resources and the probability of choosing livestock species vary with eco-region and land use/cover that indicates the need for site-specific feed and rangeland management scheme.
\end{abstract}

\section{Land Use/Cover Change analysis and its Implication on Livestock Feed Resource Availabilities in Southeastern Rangeland of Ethiopia}

Matiwos Habte ${ }^{\mathrm{ab}}$, Mitiku Eshetu $^{\mathrm{c}}$, Melese Maryo $^{\mathrm{d}}$, Dereje Andualem ${ }^{\mathrm{b}}$ and Abiyot Legesse

${ }^{a}$ African Center of Excellence for Climate Smart Agriculture and Biodiversity Conservation, Haramaya University, P.O.Box 138 Dire Dawa, Ethiopia

b Department of Animal and Range Sciences, Dilla University, P.O.Box 419 Dilla, Ethiopia

${ }^{c}$ School of Animal and Range Sciences, Haramaya University, P.O.Box 138 Dire Dawa, Ethiopia

d Ethiopian Biodiversity Institute, Ethiopia

e Department of Geography and Environmental Sciences, Dilla University, P.O.Box 419 Dilla, Ethiopia 
Corresponding author email:matiwosh@gmail.com / matiwosh@du.edu.et

\begin{abstract}
The objective of this study was to analyze the combined effects of climate and land use/cover changes on livestock feed resources and livestock species composition. The land use/cover data were generated from Landsat images of 1986, 1995, 2010 and 2018. The images were classified using a maximum likelihood classifier algorithm. The result from meteorological data and the land use/cover change were compared with household perception on livestock feed availability and livestock species composition. The result showed that the dominant land use/cover in the eco-region throughout the study period was bush/shrub cover followed by woody vegetation. This study revealed transition of land use/cover from grassland, woody and forest vegetation cover to bush/shrub and cropland in the study areas. The analysis of time series meteorological data showed significantly increasing patterns of temperature, and the highly variable nature of rainfall during 1986-2018. The pattern of livestock population throughout the analysis period exhibited a significantly increasing trend. The land use/cover, temperature and rainfall significantly affected livestock feed availability and quality. Over the last 32 years, potential grazing resources had been declined with a resultant increase in the proportion of bush/shrub feed resources available for livestock. The inter-annual variation of rainfall during the analysis period was $40.45 \%$, which implies that the rangeland is in non-equilibrium dynamics. The rangelands carrying capacity was significantly decreased from 3.76 TLU/ha/year in 1986 to 1.74 TLU/ha/year in 2018. However, the stocking rate was increased from $1.8 \mathrm{TLU} / \mathrm{ha} /$ year in 1986 into $7.15 \mathrm{TLU} / \mathrm{ha} /$ year during 1986-2018. It is recommendable to choose camel and goat more likely than cattle and sheep raising with increasing temperature and decreasing pattern of rainfall that favour bush/shrub feed resources. Hence, available feed resources and the probability of choosing livestock species vary with eco-region and land use/cover that indicates the need for site-specific feed and rangeland management scheme.
\end{abstract}

Keyword: Land use/cover; Feed resource; Livestock; Climate; Rangeland

\title{
INTRODUCTION
}

Climate and land use/cover change have strong interconnection and the concurrent mutual influence on each other (Dale, 1997; Fan, Ma, Yang, Han, \& Mahmood, 2015). According to Fahey, Doherty, Hibbard, Romanou, and Taylor (2017), land-use changes such as deforestation and soil cultivation changes the surface brightness. The positive radiative forcing (lower land surface albedo) can produce through the abandonment of pasture and forest cover. Research findings indicate that conversion of land use/cover to agriculture is a crucial driver of climate change. For instance, agricultural activities (crop with livestock) carried out in the field directly accounted for $13.5 \%$ of GHG emission. Whereas clearing forest for agriculture roughly accounted for an additional 17\% of global GHG emission (Faurès et al., 2013). Furthermore, conversions of pastureland/ native vegetation to cropland in semi-arid environments decreased soil organic carbon stock by $30 \%$ within five years of cultivations (Lipper, McCarthy, Zilberman, Asfaw, \& Branca, 2017). Conversion of tropical forest to agriculture accounts for more than $60 \%$ of soil carbon loss (Eshetu \& Hailu, 2020).

Land use/cover changes are mainly caused by human activities including overgrazing, expansion of built-up, forest clearing and cultivation (Feddema et al., 2005; Garedew, Sandewall, Söderberg, \& Campbell, 2009; Homewood et al., 2001; IPCC, 2019; Reid et al., 2000). According to Benin, Ehui, and Pender (2003) and IPCC (2019), changes in land use/cover patterns and climate variabilities are primarily changing livestock feed resources in terms of composition, availability and quality. Under the dynamics of land use/cover changes and climate variability, the livelihood of pastoral communities is under threat (Elias, 2008; Gebru, Desta, \& Coppock, 2003; Müller, Linstädter, Frank, Bollig, \& Wissel, 2007). Furthermore, Benin et al. (2003) and Aklilu, Gerard, Kindie, Lisanework, and Duncan (2014) revealed declining patterns of grazing feed resources due to the combined effects of land use/cover and climate change. Moreover, Wolde-Georgis, Aweke, and Hagos (2000), Hidosa and Guyo (2017) and Husein (2018) reported that the quality and availability of natural pastures are considerably affected by continuous land use/cover and climate change. The supply of quality feed with the required quantity determines livestock productivity (Tolera, Yami, \& Alemu, 2012). In Ethiopia, livestock feed resources are mainly derived from foraging over large areas of grazing and browsing 
lands (Mengistu \& Salami, 2007; Tolera et al., 2012). However, the contribution of free-ranging feed resources is subjected to the types and species of livestock reared (Rahman et al., 2008).

The current growing concern of scientists is mainly focused on investigating how and to what extent climate and land use/cover changes are affecting livestock feed resources bases in pastoral regions (Nelson, 2012; Oba, 2012). Forage availability, pastoral herd mobility and herd composition are primarily affected by the current dynamics of climate and land use/cover changes. Land use/cover and climate change significantly vary across the agro-climatic condition, topography/altitude, and types of main livelihood and production system (Deressa, 2007; Yesuph \& Dagnew, 2019; Žurovec \& Vedeld, 2019). According to Faurès et al. (2013), climate impact mitigation and adaptation potentials depend on the agro-climatic condition and land use/cover types. Therefore, possible interventions could be provided depending on intensity and types of land use/cover and specific to particular environments (Dale, 1997).

According to FAO (2015), livestock diversity, both species and genetic, is a source of resilience and facilitates adaptations in the face of environmental challenges. Species and genetic diversity are potentially required to cope up with the continual changes in climate, feed resources and newly emerging diseases. The adaptive capacity of livestock species to climate extremes and harsh environmental condition is likely to sustain the livelihoods of the producers. The livelihoods of the poor pastoral community depend on diverse livestock species, and hence the value of species diversity remains essential in the face of environmental challenges.

Land use/cover change studies have extensively conducted concerning drivers of the change and drought vulnerability (Aklilu et al., 2014; Meshesha, Tsunekawa, \& Tsubo, 2012; Reid et al., 2000). However, few studies dealt with livestock feed availability with land use/cover change (Aklilu et al., 2014) and none have dealt with the availability of livestock feed resources with climate and land use/cover changes in the southeastern pastoral region of Ethiopia.

The interconnection of climate and land use/cover change with household perception on trends of livestock feed resources is less understood. The current trends of climate and land use/cover changes and its potential impacts on the availability of livestock feed resources, pastoral herd composition, grazing land, the viability of livestock production and livelihoods of pastoral communities have not yet investigated in a southeastern pastoral region of Ethiopia. Furthermore, integrating land use/cover and meteorological information with ground-based community perception could provide a complete picture of the combined effects of climate and land use/cover change on livestock feed availability and its driving factors on herd composition. Therefore, this study presents the combined effects of climate and land use/cover change on livestock feed resource availabilities and livestock species composition in east Guji zone of southeastern pastoral region of Ethiopia.

1. MATERIAL AND METHODS

2. Description of the study area

East Guji zone is one of the zones in Oromia regional state and is the richest in livestock production in southeastern Ethiopia. NegelleBorana is the capital town of the Zone, which is located $610 \mathrm{~km}$ to the southeast of Addis Ababa. Three pastoral and agro-pastoral districts with the similar agro-ecological condition, namely Goro-Dola, Liban and Gumi-Eldallo, were selected for this study. The selected districts lie between $4^{0} 38^{\prime}$ $55^{\prime \prime}$ and $5^{\circ} 33^{\prime} 7^{\prime \prime} \mathrm{N}$ latitude and $39^{\circ} 9^{\prime} 25^{\prime \prime}$ and $39^{\circ} 58^{\prime} 37^{\prime \prime} \mathrm{E}$ longitude. The study locations cover about $742,644.14$ ha. The districts are located at a lower altitude (1370 and 1560 m.a.s.l). Thus, the climatic condition of the study area is a mostly semi-arid condition with the bimodal rainy season. The average annual rainfall is about $526.75 \mathrm{~mm}$, and the temperature ranges from 24 to 30 (Adi \& Swoboda-Reinhold, 2003; Aklilu et al., 2014). The soil type of the rangelands in the study areas are mainly vertisols (Abate, 2016; Dalle, Maass, \& Isselstein, 2006).

1. Data collection

2. Land use/cover change analysis methods

3. Data sources and methods of data collection

Land use/cover change analysis was conducted using time-series satellite imageries downloaded from USGS 
web site (https:/glovis.usgs.gov/). Landsat images of 1986, 1995, 2010 and 2018 with 167 path and 056/057 rows were used to generate land use/cover. As the study is large in size, two adjacent Landsat images were downloaded for each period (Table 1).

Image analysis methods

The analysis was conducted in three different stages such as pre-processing, image classification and postprocessing. In the pre-processing stage, the images were checked for their geometric and radiometric errors. As the images downloaded from USGS are already geo-referenced, there is no need to conduct geometric correction. With regard to radiometric errors, all the images were subjected to haze reduction and atmospheric correction. Once the images were checked for their geometric and radiometric errors, the adjacent images were mosaicked using ERDAS IMAGINE 14 software.

In the image classification stage, 24 sample-training areas were collected from each land use/cover type and used for training as well as accuracy assessment. Maximum likelihood classifier algorithm was used to classify the images. Accordingly, six different land use/cover classes such as agricultural land, bushland, forestland, woodland, grassland and settlement were generated.

In the third stage, the classified images were checked for accuracy using accuracy assessment technique. The training areas used for image classification were used to assess the accuracy of the classified images as well. Kappa coefficient was computed, and report about producer and user accuracy was generated. In addition, a change matrix was computed in ERDAS IMAGINE 14 software to determine the contribution of each land use/cover class.

\section{Estimation of potential dry-matter production of different land-use type}

Rangeland condition assessment was conducted at different years in the same study area, and the condition varies over time. Potential dry-matter supply of the rangeland during 1986, 1987-95 and 1996-2010 was estimated using Wroe (1988) based model. The model considers the range of precipitation and rangeland condition of the study area. Average annual precipitation of the study area falls within the range of 550-650 mm at all study period (1986, 1987-1995 and 1996-2010). Accordingly, excellent and fair rangeland condition was considered to determine the potential dry matter supply of grassland in 1986 and 1987-1995, respectively. At the same time, the average of good and excellent rangeland condition was used to estimate total pasture supply of grassland during 1986. The grassland forage supply of the study area for 2018 was estimated from the sample taken from two different enclosed Kalo (reserve grazing). About 37 sample plots were selected from two different sites the grass was cut at the ground during the beginning of May (5-10) by throwing 1 $\mathrm{m}^{2}$ quadrant to measure the total dry matter supply in the field. The clipped grasses were dried at room temperature over several days, and then dried sample weight was weighed using digital sensitive balance and recorded. Thus, the average value of dry-matter productivity from the whole plots was used to estimate the total dry matter supply of the grassland in the study area.

The total dry matter supply of bush or shrubland, woodland and dry forest were determined using a simplified simulation model of Timberlake and Reddy (1986). The model considers potential evapotranspiration (PET), annual rainfall and soil water retention capacity of the study area. Annual rainfall and temperature data were obtained from the national meteorological agency, Ethiopia. Potential evapotranspiration data was determined from the monthly average maximum and minimum temperature using DrinC software version 1.7 (91). About $233 \mathrm{~mm}$ of water retention capacity of the soil was used, since vertisols at a depth of 0-1.5 $\mathrm{m}$ can have $233 \mathrm{~mm}$ of water retention capacity in the lowland of Ethiopia (Virmani, Sahrawat, \& Burford, 1982). About $75 \%$ of utilization potential was considered since the woodland, shrub and dry forest flora of tropical Africa contain about $75 \%$ of browse species that can be potentially utilized by goat and camel (Wickens, 1980).

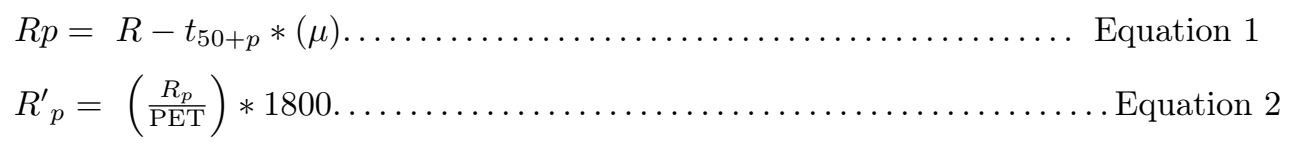




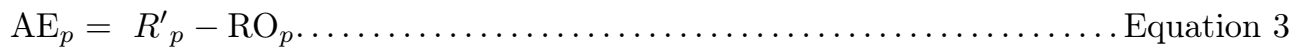

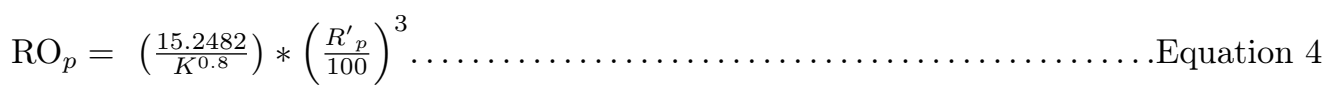

\section{Where}

$R$ is mean annual rainfall of previous years $(\mathrm{mm})$

$\mu$ is the standard deviation of mean annual rainfall

$t_{50+p}$ is t-value at $50+p$ per-cent probability level

$R_{p}$ is expected annual rainfall at probability, $\mathrm{p}(\mathrm{mm})$

PET is potential evapotranspiration

$R_{p}^{\prime}$ is effective annual rainfall at probability $\mathrm{p}(\mathrm{mm})$

$\mathrm{RO}_{p}$ is annual runoff at probability $\mathrm{p}(\mathrm{mm})$

$\mathrm{AE}_{p}$ is actual annual evapotranspiration at probability $\mathrm{p}(\mathrm{mm})$

$K$ is available water holding capacity at probability $\mathrm{p}(\mathrm{mm})=233 \mathrm{~mm}$

Determination of total forage Forage supply of the rangeland

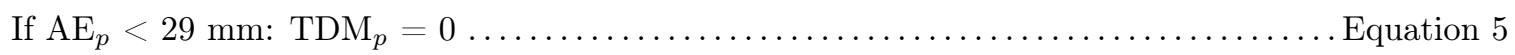

If $29 \mathrm{~mm} \leq \mathrm{AE}_{p} \leq 263 \mathrm{~mm}$ :

$\mathrm{TDM}_{p}=\left(3.32 *\left(\mathrm{AE}_{p}-29\right) *\left(1.613 \pm 0.613 *\left(\frac{F-1}{125}\right)^{0.5}\right) \ldots \ldots \ldots \ldots \ldots\right.$ Equation 6

If $\mathrm{AE}_{p}>263 \mathrm{~mm}$ :

$\mathrm{TDM}_{p}=\left(777+6.26 *\left(\mathrm{AE}_{p}-263\right) *\left(1.613 \pm 0.613 *\left(\frac{F-1}{125}\right)^{0.5}\right) \ldots\right.$ Equation 7

NB: If $\mathrm{F}-1>0$, use positive value for \pm while use negative value if $\mathrm{F}-1<0$

Where

$\mathrm{TDM}_{p}$ is potential dry-matter production of pasture $(\mathrm{kg} / \mathrm{ha} /$ year $)$

$\mathrm{AE}_{p}$ is actual evapotranspiration $(\mathrm{mm})$

$F$ is supper phosphate fertilizer level (for this study, $\mathrm{F}$ value $=0$ since there is no fertilizer application in the rangeland of the study location).

\section{Carrying capacity of grasslands}

In this study, $30 \%$ of the potential utilization rate of grassland used as proposed by Cossins and Upton (1987) while $20 \%$ use rate of bush/shrub, woodland and the dry forest were adopted as recommended by Caltabiano (2006) for Mulga pastures in southern Ethiopian rangeland. About $75 \%$ of woodland, shrub/bush and dry forest flora of tropical Africa are palatable of browse species for the animal (Wickens, 1980). Therefore, 0.75 palatability rate of woody, shrub/bush and forest vegetation cover was used.

The concept of tropical livestock unit (TLU) was used to compute the carrying capacity of the rangeland. The TLU was used to convert all livestock types into common denominator using the conversion factor of 0.7 for a cow in the herd, 0.1 for sheep, 0.08 for goat and 1.25 for a camel. An animal weighing $250 \mathrm{~kg}$ with $6.25 \mathrm{~kg}$ of daily dry matter intake is considered as one tropical livestock unit (Houerou \& Hoste, 1977). Once the total forage supply and utilization rate of the rangeland estimated, the carrying capacity was determined. 
The information was presented as the maximum number of animal that the system can carry (TLU/ha/year) and areas required to graze/browse for specific herds (ha/TLU/years).

$$
\mathrm{CC}\left(\mathrm{kg} \text { of live weigh } \mathrm{ha}^{-\mathbf{1}} \mathrm{year}^{-\mathbf{1}}\right)=\text { potential yield of TDM } * \text { usable rate }(\mathbf{3 0} \%) * \frac{\mathbf{1 0 0}}{(\mathbf{2 . 5} * \mathbf{3 6 5})}
$$

The stocking rate was also determined using a factor for grassland and $20 \%$ use factor for bush/shrub; woodland and forestland cover type, which indicates the total number of livestock on the feeding area for a specific period (TLU/ha/year).

$$
\text { Stocking rate for the year in TLU ha }{ }^{-1} \text { year }^{-1}=\frac{\text { TLU }}{\text { Total grazing/browsing area }}
$$

\section{Household survey}

The pastoral and agro-pastoral people perception data were collected using semi-structured questionnaires regarding the interconnection of climate and land use/cover change on livestock feed availability and quality. The primary survey data were used to triangulate the respondent's perception with the interpretation of land use/cover and meteorological data. The interviewed household heads were selected using systematic random techniques, and the sample size was determined using the simplified formula provided by Yamane (1967) and Israel (1992) at a 95\% confidence interval and 7\% precision level (sampling error). From the total number of 2,441 livestock owner including camel, 198 household heads were selected for interview. The interviews were conducted in a face-to-face approach in the house of respondents, and some are interviewed at public meeting places or occasionally in other places. Furthermore, the available livestock feed resources were identified during the group discussion made with the selected pastoral; agro-pastoral and livestock feed experts of the study site

$\mathrm{n}=\frac{N}{1-N(e)^{2}}$

where $\mathrm{n}$ is sample size, $\mathrm{N}=$ total household of selected kebels, $\mathrm{e}=$ precesion level, $\mathrm{z}=1.96$ (at 95\%).

where $\mathrm{ni}=$ assigned sample size of kebeles or wealth rank, $\mathrm{n}=$ Total sample size, $\mathrm{Ni}=$ Household size of single kebeles or single wealth group, $\mathrm{N}=$ Total household size

Sample Size $=\mathbf{n}=\frac{2441}{1-2441(0.07)^{1.96}}$

$=198$

\section{Data analysis}

Livestock and potential rangeland productivity data were analyzed using SPSS version 20 and Microsoft Excel program Version 2016 to generate descriptive statistics. ERDAS2010 and Arc-GIS version 10 software's were used to analyze spatial land use/cover change data and map LULC. Potential evapotranspiration data was determined from the monthly average maximum and minimum temperature using DrinC software version 1.7 (91). Multinomial logit model (MNL) was used to analyze the survey data types of adaptation of livestock species and livestock species preference towards temperature, rainfall and feed availability. Trends of temperature, rainfall and livestock population data were analyzed by undertaking linear trend analysis. Mann-Kendall's test for trend significance was also used.

\section{RESULTS AND DISCUSSION}

2. Land use/cover change analysis (1986-2018)

The dominant land use/cover change during the entire analysis period of this study was bush/shrubland, followed by woody vegetation cover (Figure 2). During the analysis period, the area under crop coverage, bush/shrub cover and settlement showed positive changes. Between 1986 and 2018 expansion of settlement was exhibited, followed by crop and bush/shrubland expansion that has increased by about 287 and $7 \%$, 
respectively. On the other hand, the area covered with woody, forest and grass vegetation has shown a decreasing trend over the entire study period with a declining rate of $18.31 \%, 41.9 \%$ and $22.46 \%$, respectively. This change indicates crop residue and bush/shrub cover becoming the primary source of livestock feed as grassland, forest, and wooded vegetation cover had been declined over the study period.

\section{Bush/shrub cover}

Bush/shrubland is mainly composed of species of Prosopis juliflora, Barleria spinisepala E. A. Bruce, Asepalum eriantherum (Vatke) Marais, Commiphora africana (A. Rich.) Engl., Commiphora schimperi (Berg) Engl., Harmsia sidoidesK. Schum, Cissus aphyllantha Gilg., Commelina africana L., Grewia villosa Willd., Aspilia mossambicensis (Oliv.) H. Willd, Acalypha fruticosa Forssk., Sansevieria ehrenbergiiSchweinf. Ex Baker and several other species.

Bush/shrub cover is the dominant land use/cover types of the study area and showed steadily increasing trend from 1986 to 2018 (Table 2). Bush/shrubland cover increased from $38.22 \%$ in 1986 to $40.81 \%$ in 2018 with an increasing rate of $6.8 \%$. Bush/shrub vegetation cover trend showed a more significant change between 1995 and 2010 with a change rate of $0.35 \%$ per year. The increasing trends of bush/shrub vegetation cover could be associated with steadily declining patterns of grass, forest and woody vegetation cover (Figure 2). In agreement with the current finding Haile, Assen, and Ebro (2010); Smit (2004) and Coppock (1994) reported an increase of mixed bush and shrub vegetation cover that has not accessible for grazing livestock species. Bush/shrub plant encroachment is increasing with the resultant decrease in grassland cover in recent decades due to rangeland degradation in Borana plateau (Negasa et al., 2014).

\section{Grassland}

The grass cover in the study area showed a consistent declining trend throughout the study period. Its area decreased from $16.62 \%$ (114,530 ha) in 1986 to $13.13 \%$ ( 88.810 ha) in 2018 . The decreasing trends of grass cover could be associated with an increasing trend of bush/shrub vegetation cover and cropland in the study location. In agreement to this finding Coppock (1994) and Smit (2004) reported an increased rate of bush/shrub cover in response to heavy grazing in Borana rangeland of Ethiopia. Moreover, Haile et al. (2010) revealed steadily declining patterns of grassland cover during the analysis period of 1967-2002. Similarly, Gessesse and Bewket (2014) \& Aklilu et al. (2014) reported consistently declining patterns of grassland during the analysis period of 1973-2007.

Grassland is the primary feed source for grazer livestock species such as cattle and sheep in the study area. The declining patterns of grass cover could result in a severe animal feed shortage and affect livestock productivity. Thus, the expanding cultivable land could be a response to address a ruminant feed shortage problem in order to provide the required feed as crop residues for the animals. The relative increase in bush/bushland cover could be a response to increasing browsers livestock species such as camel and goat in order to secure the required feed demand of camel and goat. According to Rotherham (2013), most palatable and productive grass species has declined with prolonged overgrazing, and hence, decreaser grass species tend to dominate with increaser herbaceous and bush plant species. Similarly, Macharia and Ekaya (2005) reported that overutilization of grassland areas tends to encroached by bush and shrub vegetation, indicating decreaser grass species dominated with poorly palatable invader plant species and affects the productivity of grazing animal species.

\section{Forest and woody vegetation cover}

The land covered with woody vegetation and forest showed a decreasing trend across the study period (Figure 2). The woodland cover is mainly contained several species of acacia, Lannea rivae (chiov.) sacleux , Dalbergia microphylla chiov and species of commiphora . woody vegetation decreased from about $26 \%$ $(175,211$ ha) in 1986 to $21 \%$ (143,138 ha) in 2018. Similarly, forestland declined from about $15 \%(100,457$ ha) in 1986 to $9 \%(58,364 \mathrm{ha})$ in 2018.

The area under woody vegetation and forest cover has shown a negative change over the study period with an average annual decreasing trend of $0.57 \%$ for woodland and $1.31 \%$ for the forest and significantly differ 
$(\mathrm{p}<0.01)$ throughout the study period. The land covered with forest vegetation was declined by $41.9 \%$ throughout the study period of 1996-2018. This result revealed that the most significant change in forest cover was observed between 2018 and 1995, while woody vegetation cover was profoundly changed between 1995 and 1986. This change might be due to shifting of the pastoral community from complete pastoralism to selling of firewoods and charcoal from wooded and forestland cover as a means of additional incomegeneration activities. According to Haile et al. (2010), the livelihoods of pastoral communities started production and selling of charcoal and firewood as a means of additional income since 1987.

In agreement with this finding Aklilu et al. (2014) reported decreasing patterns of forest cover over the study period of 2007-1973 at the same study location. However, Haile et al. (2010) reveal that increasing patterns of woody vegetation cover between 1967 and 2002 in Borana zone under a similar agro-ecological condition with this study. Such variation could be due to the difference in spatial classification of LULC change types of the rangeland. However, wooded vegetation and forest cover were independently treated in the current study.

\section{Cropland cover}

The increasing patterns of cropland coverage were detected over the analysis period in the study areas. Land covered with cultivable land was about $4 \%$ (28,018 ha) in 1986, $8 \%$ (53,895 ha) in $1995,12 \%$ (78,902 ha) in 2010 and $16 \%$ (108,520 ha) in 2018. The cultivated cropland increased by $92.4 \%$ between 1995 and 1986, with an average annual change of $9.24 \%$. At the same location, $37.54 \%$ of woody vegetation cover increase was recorded between 2010 and 2018, with an average change of $4.5 \%$ per year. The result of this study showed that there was $287.32 \%$ increase in cultivated land over the entire study period, giving an annual average change of $8.98 \%$. In line with this finding Aklilu et al. (2014) reported an increased cropland cover by $8.3 \%$ over the analysis period (1973-2007) at Liban district of southeastern parts of Ethiopia. According to Haile et al. (2010), cultivable land was showed a rapid increase since 1987 in southern Ethiopian rangeland.

\section{Carrying capacity (CC) of rangeland}

The rangeland productivity and carrying capacity were declined from 1986 to 1995 (Table 3 \& 4). Decreasing patterns of feed availability were consistent with the perception of selected respondents. Reduced carrying capacity in the study area might be due to hydrological drought, which occurred in 1990, 1991, 1992, 2015 and 2016. The potential carrying capacity reported in this study might underestimate the actual carrying capacity of the study area because cropland cover is increasing that can supplement natural pastures but not included in this study.

The bush/shrubland cover remained the most significant potential feed resources of the rangeland in the study area during the analysis period (1986-2018) (Table 3). However, carrying capacity of bush/shrubland was showed a significant decreasing pattern over the years. The potential carrying capacity of the bush/shrubland cover was decreased from 205,158.73 TLU in 1986 to 102,795.68 TLU in 2018. The maximum number of livestock that can browse in bush/shrubland for one year was about $27 \%$ (205,158.73 TLU) of the total carrying capacity of the rangeland in 1986 while about $44 \%$ (102,795.68 TLU) of the total carrying capacity of the rangeland during 2011-2018 (Table 3). The existing carrying capacity of bush/shrub cover in the study area, in general, where showed a declining pattern. However, bush/shrub cover remained the primary livestock feed resources and the most significant livestock support service of the total rangeland carrying capacity of the study area.

The maximum number of animal that can feed/browse on woody and forest vegetation cover was about $38 \%(218,571 \mathrm{TLU} / \mathrm{ha} /$ year $)$ of the total carrying capacity of the rangeland in 1986 but after that declined to about 35\% (143,496 TLU/ha/year) and 32\% (74,955 TLU/ha/year) during 1987-1995 and 2011-2018, respectively (Table 3 ). The woodland and forest vegetation cover is an alternative feed resource of browser livestock species (camel and goat) that can mainly supplement grassland. The woody vegetation cover was the third valuable livestock holding capacity in 1986 (about 24\%) and during 1987-1995, which was about 24 and $21 \%$ of the total carrying capacity of the rangeland, respectively. However, it was the second-largest stocking capacity of the total rangeland carrying capacity during the analysis period of 1995-2010 (29\%). 
According to Giday, Humnessa, Muys, Taheri, and Azadi (2018), the maximum number of livestock that can be raised on Desa'a forestland cover was about 68,480.39 TLU/year in northern Ethiopia, which was higher than the forest carrying capacity value of the 2011-2018 and comparable with the value of 1986-2011 in this study. This variation might be due to decreasing trends of forestland cover in the eco-environments of this study.

Of the total carrying capacity of the rangeland in the study area, the grassland cover stock holding capacity was declined from about 158,483 TLU/year in 1986 to 55,181 TLU/year during the analysis period of 20112018 (Table 3). This study showed a decreasing rate of $23.93 \%$ between 1995 and 1986, 24.88\% between 2010 and 1995, and $34.78 \%$ between 2018 and 2010 . The grazing capacity of grassland was declined by $65.18 \%$ between 2018 and 1986 with an annual decreasing rate of $2.04 \%$.

The average value of bush/shrubland carrying capacity is about $0.8 \mathrm{TLU} / \mathrm{ha} /$ year in 1986 and 0.4 TLU/ha/year during 2011-2018. The bush/shrubland carrying capacity value of 1986 is higher than the report of Pratt and Gwynne (1977). These authors reported 0.2 TLU/ha/year for east Africa under the same climatic condition, and it is comparable with the result of 2011-2018 of this study. The average value of bush/shrubland carrying capacity during 1987-1995 of this study is in agreement with the report of Mugerwa (1992) who reported 1.63 ha/TLU grazing/browsing capacity. However, carrying capacity of bush/shrubland from 1996 to 2010 was relatively lower than the finding of Byenkya (2004) who reported $2.27 \mathrm{ha} / \mathrm{TLU}$, and it is comparable with this finding value of 2011-2018 (2.7 ha/TLU).

The potential carrying capacity of woody and forestland cover was declined from $1.58 \mathrm{TLU} / \mathrm{ha} / \mathrm{year}$ in 1986 to $0.74 \mathrm{TLU} /$ ha/year during 2011-2018 (Table 4). The average carrying capacity of wooded and forestland cover during 1986-2010 in this study was comparable with the finding of Hocking and Mattick (1993) who reported 2.5-3.5 ha/TLU in woody vegetation cover of Tanzania. The reason for the declined carrying capacity of woody and forest vegetation cover could be attributed to decreased biomass production that might be as a result of relatively decreasing patterns of rainfall, increased rate of temperature and solar radiation.

The average carrying capacity of grassland in the study area was decreased from $1.38 \mathrm{TLU} / \mathrm{ha}$ ( $0.72 \mathrm{ha} / \mathrm{TLU})$ to $0.62 \mathrm{TLU} / \mathrm{ha}$ (1.62 ha/TLU) during 2011-2018 (Table 4). Such a decreasing rate may be due to declining trends of rangeland condition and rainfall patterns of the study area. Increasing patterns of drought years, solar radiation and temperature pattern could be the significant factors for depleting grassland productivity. The carrying capacity value of 2011-2018 in this study was agreed with the finding of Meshesha, Moahmmed, and Yosuf (2019) who reported $4.9 \mathrm{ha} / \mathrm{TLU} /$ year of grassland under the similar microclimatic condition. However, the carrying capacity value of grassland in 1986 was much higher than the report of Pratt and Gwynne (1977) who revealed 0.2 TLU/ha under similar ecological condition. The grassland carrying capacity of the study area during 1987-1995 was relatively higher than Mugerwa (1992) report of $1.63 \mathrm{ha} / \mathrm{TLU} /$ year for rangelands of Uganda. Similarly, Byenkya (2004) reported 2.27 ha/TLU grazing capacity of southwestern Uganda, which is higher than the carrying capacity value of 1996-2010 of this study. Therefore, the grassland productivity and carrying capacity of the current finding indicate that the grassland is relatively a good condition.

The decreasing trends of grassland carrying capacity could be due to declining rangeland condition in the study area. Similarly, Angassa and Baars (2000) reported good rangeland condition based on the data collected in 1998. In contrast, Dalle et al. (2006) reported fair rangeland condition from a similar study location to the current study.

\section{Stocking rate}

The overall stocking rate of the rangeland shows an increasing pattern in the study area (Table 5). The general stocking rate was $1.8 \mathrm{TLU} /$ ha in 1986, which is much lower than the carrying capacity value of the same year $(3.76 \mathrm{TLU} / \mathrm{ha} /$ year). Whereas, the total stocking rate of the rangeland during 1987-1995 was consistent with the estimated carrying capacity (2.79 TLU/ha) of the same analysis period. However, the general stocking rate of the rangeland was about $5 \mathrm{TLU} /$ ha/year and 7.2 TLU/ha/year during 1996-2010 
and 2011-2018, respectively and it is much higher than the carrying capacity of the rangeland (Table 4).

The existing browser livestock species-stocking rate of bush/shrubland of the study area was 0.77 TLU/ha/year in 1986, $2.63 \mathrm{TLU} /$ ha/year during 1987-1995, $7.28 \mathrm{TLU} /$ ha/year 1996-2010 and 9.38 TLU/ha/year during 2011-2018. The current stocking rate in this study relatively comparable with carrying capacity in $1986(0.79 \mathrm{TLU} / \mathrm{ha})$ and much higher than its carrying capacity during 1987-1995 (0.56 TLU/ha), 1996-2010 (0.64 TLU/ha) and 2011-2018 (0.37 TLU/ha).

The estimated stocking rate of the grass vegetation cover was $5.12 \mathrm{TLU} /$ ha in 1986 and $11.79 \mathrm{TLU} / \mathrm{ha}$ during 2011-2018 based on grazer livestock species while 5.99 TLU/ha in 1986 and $26.4 \mathrm{TLU} /$ ha in 2018 based on the total livestock population in the study area. Thus, the grassland stocking rate was much higher than its carrying capacity throughout the analysis period $(1.38,1.11,0.83$ and $0.62 \mathrm{TLU} /$ ha in $1986,1995,2010$ and 2018, respectively). The grassland-stocking rate in this study showed a consistently increasing pattern throughout the analysis period, with the average increasing rate of $10.64 \%$ per year (Table 5). The stocking rate of grass vegetation cover was augmented by $52.1 \%$ between 1986 and 1995, with an average change of $5.21 \%$ per year. Moreover, grassland stocking was increased by $54.3 \%$ between 2018 and 2010 with an annual change of $6.8 \%$. The stocking rate observed in this study during the analysis period of 2011-2018 was much higher than the finding of Meshesha et al. (2019) who revealed 5.4 TLU/ha/year for grassland cover of similar ecological condition with the site of this study. This variation could be associated with an existing livestock population that can graze in the current study area.

The current stocking rate of woody vegetation and forest cover showed a consistently increasing trend throughout the study period (Table 5). The stocking rate in the forest and woody vegetation cover was about $3.12 \mathrm{TLU} /$ ha for browser livestock species in 1986 while it was increased to $62.51 \mathrm{TLU} / \mathrm{ha}$ during 2011-2018. The woody vegetation and forest cover stocking rate in this study is much higher than its carrying capacity (Table 4 and 5). There was a more significant change in stocking rate of woody vegetation and forest cover with a $59.5 \%$ increase per year for browser livestock species. The stocking rate of woodland and forest cover pattern was increased by about 2.6 folds (259\%) between 1995 and 1986, giving an average change of $26 \%$ per year. The stocking rate of forest and woody vegetation cover was increased by $51 \%$ between 2018 and 2010, giving an average increasing pattern of $5.7 \%$ per year. Moreover, the stocking rate for browser livestock species was increased by 19 folds (1904\%) between 2018 and 1986, giving an average change pattern of $59.5 \%$ per year. This decreasing may be due to the declining pattern of rangeland productivity and increasing trends of browser livestock population in the study area.

\section{Sustainability of grazing/browsing of the rangeland in the study area}

The relative contribution of grassland was significantly enormous in the past and showed decreasing pattern from year to years with a resultant increase in invasive unpalatable woody vegetation that could be mainly available for browser livestock species such as camel and goat. The contributions of feed resources from grassland, woody and forest vegetation cover has shown decreasing pattern. Conversely, the area covered with bush/shrub and cultivated cropland was increasing throughout the analysis period. This difference might be due to variability and erratic nature of rainfall, decreasing rate of relative humidity and positive change in temperature of the study area throughout the study period.

The meteorological data from 1986 to 2018 indicates that there is no significant variation among annual rainfall. However, 13 drought years (1988, 1991, 1992, 1998, 1999, 2000, 2007, 2009, 2010, 2012, 2015, 2016 and 2017) were identified using rainfall anomaly index. The calculated mean annual rainfall and CV value, excluding drought years were $694.37 \mathrm{~mm}$ and $11.28 \%$, respectively. However, the mean annual rainfall and CV value during the whole analysis period (1986-2018) were $555.43 \mathrm{~mm}$ and $40.45 \%$, respectively. Rangeland dynamics of the study area becomes a non-equilibrium system throughout the study period, since rainfall with greater than $33 \%$ of $\mathrm{CV}$ value during the analysis period was qualified as non-equilibrium dynamics (Ellis, Coughenour, \& Swift, 1993; Vetter, 2004).

In contrast, it becomes near-equilibrium dynamics when the drought years are excluded. In agreement with this finding Meshesha et al. (2019) indicated that the near-equilibrium of rangeland was observed by 
excluding the drought years during the analysis period of 2000 to 2018. The management of the rangeland in the equilibrium dynamics should follow Clementsian succession theory Clements (1916) and should be utilized by keeping numbers of livestock below its carrying capacity while minimizing the number and increasing livestock productivity (Caughley, 1979).

The current stocking rate over the analysis period in this study showed consistently increasing beyond its carrying capacity. The stocking rate and carrying capacity of the rangeland during the analysis period showed a negative correlation (Figure 4). According to Engler, Abson, Feller, Hanspach, and von Wehrden (2018) and Vetter (2004), the high number of livestock in the rangeland was responsible for overgrazing, particularly in East African rangelands. Therefore, all pastoral development endeavor should be implemented by considering proper rangeland management schemes through maintaining carrying capacity of the rangeland with an appropriate number of high producing livestock species, destocking a colossal number of poor livestock producers, resettlements of nomadic pastoralists into villages and conversion of communal pasture area into private tenure scheme.

The trend analysis using Mann-kendall non-parametric test of significance showed significantly increasing pattern of mean annual temperature, cattle, goat and camel population in the time series data of the study area. In contrast, significant declining trends of sheep population and non-significant decreasing patterns of annual rainfall was observed during the study period (Table 6). The declining trends in sheep population suggested that poor adaptive capacity to increasing temperature, reduction in the amount of rainfall and grassland productivity.

Majority $(p<0.01)$ respondents perceived decreasing patterns of feed availability $(74.2 \%)$, feed quality $(65.2 \%)$ and water availability $(83.3 \%)$ (Table 7$)$. The declining trends of feed and water resources may be associated with increasing patterns of temperature and decreasing trends of rainfall in the study area. The result of this finding has agreed with the report of Angassa and Oba (2007) who revealed that the amount of rainfall and distribution determine forage production. Camel and goat population and rising temperature could have a positive relationship that can be due to increased bush/shrub vegetation cover and browse forage species in the study area.

As shown in Table 8 , the majority of respondents had perceived that decreasing trends of available feed resources $(75.6 \%)$ and feed quality $(64.6 \%)$ corresponding with increasing patterns of temperature. Pastoralist's and agro-pastoralist perceived significant decreasing $(\mathrm{p}<0.01)$ patterns of feed availability $(78.8 \%)$ and quality $(66.4 \%)$ while the amount of rainfall is too little. This perception indicates that significant decreasing patterns of feed availability and quality corresponds with the perceptions of increasing trends of temperature and too little amount of rainfall. This study suggested that decreasing rate of feed availability and quality had associated with increasing patterns of temperature and declining patterns of rainfall.

The respondents perceived that decreasing amount of rainfall, increasing patterns of temperature, encroachments of bush and poisonous plant species are the primary determinant factor of livestock feed quality and availability in the rangeland. The vegetation cover identified during discussion available with household heads includes an increasing level of the invasive bush, poisonous (Xanthium, Parthenium hysterophorus $L$ and Prosopis hysterophorus) and thorny plant species (Acacia mellifera and Acacia Senegal). Household heads also stated decreasing trends of palatable grass and browse species such as elephant grass and Acacia brevispica. Decreasing feed availability and quality perception of the respondents might be due to increasing patterns of temperature and decreasing trends of rainfall parameters (Onset, duration and amounts of rainfall). This finding agreed with the report of Abebe et al. (2012) who revealed increasing rate of poisonous, thorny and invasive bush and declining trends of grass plant species due to drought and erratic nature of rainfall in Borana rangeland. Ort and Ainsworth (2012) revealed that environmental changes are rapid to some plant species, and they become powerless to respond while some species may develop adaptive capacity with the extant genetic diversity in changing eco-environment. According to Rust and Rust (2013) and Warne, Pershall, and Wolf (2010), most pasture and grass species $\left(\mathrm{C}_{3}\right.$ plants) are more productive under cooler and moist eco-environment while $\mathrm{C}_{4}$ plant species are more productive under high temperature, low moisture and high solar radiation. Furthermore, Barker and Caradus (2001) reveal that $\mathrm{C}_{4}$ plant species 
are more desirable under global warming scenario for tropical and subtropical regions. However, the higher vegetative productivity of $\mathrm{C}_{4}$ plants under such increased temperature and solar radiation and decreased rainfall (moisture) are at the expense of feed quality and quantity (USEPA, 2016; Valtorta, 2002).

As shown in Figure 5, preferences of livestock species as farm animal by pastoral and agro-pastoral communities varied across temperature patterns and amount of rainfall. Camel is more likely chosen with increasing patterns of temperature and too little amount of rainfall. As indicated in Table 8, the perception of respondents regarding the adaptation of livestock species to low feed quality and availability have shown the camel $(53.7 \%)$ is more likely adapted $(\mathrm{p}<0.01)$ at increasing patterns of temperature followed by a goat $(25.6 \%)$. Similarly, camel $(52.5 \%)$ is more likely adapted to low-quality feed when the amount of rainfall is too little. This finding revealed that the camel and goat are the species that are well adapted to low-quality feed when the temperature is increasing, and the amount of rainfall is declined. Livestock species diversity is a means of livelihood resilience strategy of pastoral and agro-pastoral community that is mainly required to coping with changes in land use/cover, climate and feed resources (FAO, 2015). According to Coppock (1994), Borana pastoralists of southern Ethiopian rangeland has shifting owned livestock species from grazer (cattle and sheep) to the browser (camel and goat) because of changing eco-environmental condition of the area. Giday et al. (2018) also reported the browse species feed availability from forest and woody vegetation cover becoming an immense contributor to livestock feed resources in dryland pastoral regions.

Comparing with goat and cattle, the probability of choosing camel in increasing patterns of temperature was significantly (P[?] 0.05 ) increased (Table 9). Comparing with camel, goat and cattle was less likely selected while the temperature is increasing. Comparing with cattle, the probability of choosing sheep was increased by $129 \%$ in declining feed resource. In comparison with sheep, cattle and goat are less likely selected when available feed resource is decreased.

Comparing with camel, goat, and cattle was less likely ( $P$ [?] 0.05 ) adapted to increasing temperature and decreasing feed availability. Significantly higher camel adaptation to increasing temperature and decreasing feed availability have associated with a lower likelihood of goat and camel. Comparing with cattle, the probability of choosing camel, goat and sheep was increased by 81,75 and $59 \%$ when temperature pattern is increased, respectively (Table 9). When the temperature is increasing, the probability of choosing cattle and sheep is decreased by 75 and $15 \%$, respectively. In comparison, the probability of choosing camel is increased by $6 \%$ as compared with a goat. In decreasing feed availability, the probability of choosing camel and sheep is increased by 5 and $9 \%$, respectively, while goat is less likely selected comparing with cattle. This variation could be due to the region has a higher potential of browser forage species derived from bush/shrub, dry forest and woody vegetation cover that is edible for goat and camel. In agreement with this finding, Mendelsohn and Seo (2007) reported decreasing probability of choosing cattle while the probability of choosing goat become more significant as temperature increases. Livestock production and productivity are severely vulnerable, is being affected by climate change and variability in Africa (Rust \& Rust, 2013).

\section{CONCLUSION}

This study revealed that southeastern Ethiopian rangelands are undergoing significant changes in the last four decades. The livestock feed availability and quality significantly affected by land use/cover changes. As a result, the rangeland carrying capacity over the analysis period (1986-2018) was significantly decreasing; associated with significantly decreasing rate of grassland and biomass productivity of forage plant species in the eco-environment of the study location. Furthermore, the stocking rate of the rangeland has significantly increased; associated with significantly increasing trends of cattle, camel, goat and decreasing patterns of rangeland biomass production.

The transition of available feed type from grazing to browsing has not been able to meet the growing amounts of required feed in the study area. This change might be associated with the declining patterns of rainfall, rangeland increasing patterns of temperature, livestock population and stocking rate, deterioration of natural ecosystems and degradation of native forage species. With increasing temperature and decreasing pattern of rainfall, the probability of choosing camel and goat is more likely than cattle and sheep. 
This study also suggested that the need for knowledge-based land use scheme; improving early warning system for climate-related disaster risk management; improving livestock genetic makeup for effective utilization of available feed resources. Moreover, adopting climate-smart livestock production scheme; improving the quality and quantity of available livestock feed resources and raising a large number of browser livestock species such as camel and goat with increasing temperature and decreasing rainfall are recommended. Hence, the available feed resources and livestock species ownership vary with climate and land use/cover indicating the need for site-specific feed and rangeland management scheme.

\section{Conflict of Interest Declaration}

No potential conflicts of interest to declare

\section{Funding}

This research was supported by the Africa centre of excellence for Climate Smart Agriculture and Biodiversity Conservation, Haramaya University, in collaboration with World Bank Group.

\section{Acknowledgement}

We thank Mr Dereje Likisa for his assistance spatial data analysis of some parameters of this research. We would also like to show our gratitude to Mr Liban Boru (Dilla University), Mr Mieso Kaweti (Haramya University, Climate Smart Agriculture PhD candidate), Mr Guye Aga (East Guji Zone livestock and fisheries office), Dr Wako Bonaya (Gumi Eldallo District Livestock health office) and Mr Kibru Alemu (Dilla University) for sharing their pearls of wisdom with us during fieldwork.

\section{Animal Welfare Statement}

'The authors confirm that the ethical policies of the journal, as noted on the journal's author guidelines page, have been adhered to. No ethical approval was required as this is an original data with no animals used for scientific purpose.'

\section{Data Accessibility Statement}

The authors declare that all data supporting the findings of this study are available within the article and its supplementary information files. However, the land use/cover change dataset analyzed during this study were derived from EarthExplorer domain of Landsat program (https://earthexplorer.usgs.gov/).

\section{REFERENCES}

Abate, T. (2016). Indigenous ecological knowledge and pastoralist perception on rangeland management and degradation in Guji Zone of south Ethiopia. Sustainable Development (15), 192-218.

Abebe, A., Eik, L. O., Holand, Ø., Ådnøy, T., Tolera, A., \& production. (2012). Pastoralists' perceptions of feed scarcity and livestock poisoning in southern rangelands, Ethiopia. Journal Tropical animal health, 44 (1), 149-157.

Adi, S., \& Swoboda-Reinhold, M. (2003). The Borana Pastoral production and Livelihood system (BPPLS), BLPDP/GTZ, Addis Ababa and Negelle/Borana Pastoral Participatory Extension Concept-PAOPEC documents worked out compiled during consultant mission of Boris Schiele-September/October. Addis Ababa.

Aklilu, M., Gerard, B., Kindie, T., Lisanework, N., \& Duncan, A. (2014). Inter-connection between land use/land cover change and herders'/farmers' livestock feed resource management strategies: a case study from three Ethiopian eco-environments. Agriculture, Ecosystems \& Environment, 188 , 150-162. doi: 10.1016/j.agee.2014.02.022

Angassa, A., \& Baars, R. M. (2000). Ecological condition of encroached and non-encroached rangelands in Borana, Ethiopia. African Journal of Ecology, 38 (4), 321-328. doi: 10.2989/10220110609485886 
Angassa, A., \& Oba, G. (2007). Relating long-term rainfall variability to cattle population dynamics in communal rangelands and a government ranch in southern Ethiopia.Agricultural systems, 94 (3), 715-725. doi: 10.1016/j.agsy.2007.02.012

Barker, D., \& Caradus, J. (2001).Adaptation of forage species to drought. Paper presented at the International Grassland Congress, Sao Paulo, Brazil.

Benin, S., Ehui, S., \& Pender, J. (2003). Policies for livestock development in the Ethiopian highlands.Environment, Development and Sustainability, 5 (3-4), 491-510. doi: 10.1023/A:1025737315629

Byenkya, G. S. (2004). Impact of undesirable plant communities on the carrying capacity and livestock performance in pastoral systems of south-western Uganda. Texas A\&M University.

Caltabiano, T. (2006). Guide to the factors influencing carrying capacities of Queensland's rangelands. www.nrw.qld.gov.au/factsheets/pdf/land/l80.

Caughley, G. (1979). What is this thing called carrying capacity. In 'North American elk: ecology, behavior and management'. MS Boyce 85 LD Hayden-Wing (Eds) , 2-8.

Clements, F. E. (1916). Plant succession: an analysis of the development of vegetation: Carnegie Institution of Washington.

Coppock, D. L. (1994). The Borana plateau of southern Ethiopia: Synthesis of pastoral research, development, and change, 1980-91 (Vol. 5): ILRI (aka ILCA and ILRAD).

Cossins, N. J., \& Upton, M. (1987). The Borana pastoral system of southern Ethiopia. Agricultural systems, 25 (3), 199-218. doi: 10.1016/0308-521X(87)90020-5

Dale, V. H. (1997). The relationship between land-use change and climate change. Ecological applications, 7 (3), 753-769.

Dalle, G., Maass, B., \& Isselstein, J. (2006). Rangeland condition and trend in the semi-arid Borana lowlands, southern Oromia, Ethiopia. African Journal of Range and Forage Science, 23 (1), 49-58.

Deressa, T. T. (2007).Measuring the economic impact of climate change on Ethiopian agriculture: Ricardian approach : The World Bank.

Elias, E. (2008). Pastoralists in Southern Ethiopia: Dispossession, access to resources and dialogue with policy makers. Oslo, Norway: Drylands Coordination Group.

Ellis, J. E., Coughenour, M. B., \& Swift, D. M. (1993). Climate variability, ecosystem stability, and the implications for range and livestock development. Range ecology at disequilibrium: New models of natural variability and pastoral adaptation in African savannas , 31-41.

Engler, J.-O., Abson, D. J., Feller, R., Hanspach, J., \& von Wehrden, H. (2018). A social-ecological typology of rangelands based on rainfall variability and farming type. Journal of Arid Environments, 148, 65-73. doi: 10.1016/j.jaridenv.2017.09.009

Eshetu, E. Y., \& Hailu, T. A. (2020). Carbon sequestration and elevational gradient: The case of Yegof mountain natural vegetation in North East, Ethiopia, implications for sustainable management. Cogent Food Es Agriculture, 6 (1), 1-15. doi: 10.1080/23311932.2020.1733331

Fahey, D. W., Doherty, S. J., Hibbard, K. A., Romanou, A., \& Taylor, P. C. (2017). Physical drivers of climate change. In D. J. Wuebbles, D. W. Fahey, K. A. Hibbard, D. J. Dokken, B. C. Stewart \& T. K. Maycock (Eds.), Climate Science Special Report: Fourth National Climate Assessment (Vol. I, pp. 73-113). Washington, DC, USA: U.S. Global Change Research Program.

Fan, X., Ma, Z., Yang, Q., Han, Y., \& Mahmood, R. (2015). Land use/land cover changes and regional climate over the Loess Plateau during 2001-2009. Part II: interrelationship from observations. Climatic Change, 129 (3-4), 441-455. doi: 10.1007/s10584-014-1068-5 
FAO. (2015). The second report on the state of the world's animal genetic resources for food and agriculture. In B. D. Scherf \& D. Pilling (Eds.), FAO Commission on Genetic Resources for Food and Agriculture Assessments. (Vol. 2). Rome, Italy Food and Agriculture Organization of the United Nations (FAO), (available at http://www.fao.org/3/a-i4787e/index.html).

Faures, J., Bartley, D., Bazza, M., Burke, J., Hoogeveen, J., Soto, D., \& Steduto, P. (2013). Climate smart agriculture sourcebook. FAO, Rome, 557 .

Feddema, J. J., Oleson, K. W., Bonan, G. B., Mearns, L. O., Buja, L. E., Meehl, G. A., \& Washington, W. M. (2005). The importance of land-cover change in simulating future climates. Science, 310 (5754), 1674-1678. doi: 10.1126/science.1118160

Garedew, E., Sandewall, M., Soderberg, U., \& Campbell, B. M. (2009). Land-use and land-cover dynamics in the central rift valley of Ethiopia. Environmental management, 44 (4), 683-694. doi: 10.1007/s00267009-9355-z

Gebru, G., Desta, S., \& Coppock, D. L. (2003). Managing risk in pastoral systems: research and outreach experiences of the Pastoral Risk management (PARIMA) project in Southern Ethiopia and Northern Kenya. Paper presented at the Challenges and opportunities of livestock marketing in Ethiopia. Proceedings of the 10th annual conferences of the Ethiopian Society of Animal Production (ESAP) held in Addis Ababa, Ethiopia, Addis Ababa, Ethiopia.

Gessesse, B., \& Bewket, W. (2014). Drivers and implications of land use and land cover change in the central highlands of Ethiopia: Evidence from remote sensing and socio-demographic data integration. Ethiopian Journal of the Social Sciences and Humanities, 10 (2), 1-23.

Giday, K., Humnessa, B., Muys, B., Taheri, F., \& Azadi, H. (2018). Effects of livestock grazing on key vegetation attributes of a remnant forest reserve: The case of Desa'a Forest in northern Ethiopia. Global ecology and conservation, 14, e00395. doi: 10.1016/j.gecco.2018.e00395

Haile, G., Assen, M., \& Ebro, A. (2010). Land use/cover dynamics and its implications since the 1960s in the Borana rangelands of Southern Ethiopia. Livestock Research for Rural Development, 22 (7), 132.

Hidosa, D., \& Guyo, M. (2017). Climate Change Effects on Livestock Feed Resources: A Review.Fish. Livest Prod, 5, 259.

Hocking, D., \& Mattick, A. (1993). Dynamiccarryingcapacityanalysisastoolforconceptualizingandplanningrangemanagementim? provements, withacasestudyfromIndia. Pastoral Development Network, 34c, Retrieved from http://www.odi.org.uk/networks/pdn/papers/34c.pdf

Homewood, K., Lambin, E. F., Coast, E., Kariuki, A., Kikula, I., Kivelia, J., . . . Thompson, M. (2001). Long-term changes in Serengeti-Mara wildebeest and land cover: pastoralism, population, or policies? Proceedings of the National Academy of Sciences, 98 (22), 12544-12549. doi: 10.1073/pnas.221053998

Houerou, L. H., \& Hoste, C. H. (1977). Rangeland production and annual rainfall relations in the Mediterranean Basin and in the African Sahelo Sudanian zone.Rangeland Ecology \&5 Management/Journal of Range Management Archives, 30 (3), 181-189.

Husein, D. H. (2018). Determinants of Food Insecurity and Coping Strategies Among Pastoral Households: The Case of Erer District, In Sitti Zone Ethiopian Somali Regional State. Sitti Zone Ethiopian Somali Regional State (February 22, 2018).

IPCC. (2019). Summary for Policymakers. In: Climate Change and Land: an IPCC special report on climate change, desertification, land degradation, sustainable land management, food security, and greenhouse gas fluxes in terrestrial ecosystems. Summary for Policymakers, In press, 36. https://www.ipcc.ch/srccl/

Israel, G. D. (1992). Determining sample size. 
Lipper, L., McCarthy, N., Zilberman, D., Asfaw, S., \& Branca, G. (2017). Climate smart agriculture: building resilience to climate change (Vol. 52): Springer.

Macharia, P., \& Ekaya, W. (2005). The impact of rangeland condition and trend to the grazing resources of a semi-arid environment in Kenya. Journal of Human Ecology, 17 (2), 143-147.

Mendelsohn, R., \& Seo, S. N. (2007). Climate change adaptation in Africa: a microeconomic analysis of livestock choice. CEEPA Discussion Paper No. 19, Centre for Environmental Economics and Policy in Africa, University of Pretoria.: The World Bank.

Mengistu, D. A., \& Salami, A. T. (2007). Application of remote sensing and GIS inland use/land cover mapping and change detection in a part of south western Nigeria.African Journal of Environmental Science and Technology, 1 (5), 99-109.

Meshesha, D. T., Moahmmed, M., \& Yosuf, D. (2019). Estimating carrying capacity and stocking rates of rangelands in Harshin District, Eastern Somali Region, Ethiopia.Ecology and Evolution, 9 (23), 13309-13319. doi: $10.1002 /$ ece 3.5786

Meshesha, D. T., Tsunekawa, A., \& Tsubo, M. (2012). Continuing land degradation: cause-effect in Ethiopia's Central Rift Valley. Land degradation 83 development, 23 (2), 130-143.

Mugerwa, J. (1992). Management and utilization of rangeland: The case of Uganda. Paper presented at the 2nd FAO regional workshop on grazing resources for East Africa, Kampala Uganda, 30th March-3rd April.

Muller, B., Linstadter, A., Frank, K., Bollig, M., \& Wissel, C. (2007). Learning from local knowledge: modeling the pastoral-nomadic range management of the himba, namibia.Ecological applications, 17 (7), 1857-1875.

Negasa, B., Eba, B., Tuffa, S., Bayissa, B., Doyo, J., \& Husen, N. (2014). Control of bush encroachment in Borana zone of southern Ethiopia: effects of different control techniques on rangeland vegetation and tick populations.Pastoralism, 4 (1), 18. doi: 10.1186/s13570-014-0018-1

Nelson, F. (2012). Natural conservationists? Evaluating the impact of pastoralist land use practices on Tanzania's wildlife economy. Pastoralism: Research, Policy and Practice, 2 (1), 15. doi: 10.1186/20417136-2-15

Oba, G. (2012). Harnessing pastoralists' indigenous knowledge for rangeland management: three African case studies. Pastoralism: Research, Policy and Practice, 2 (1), 1. doi: 10.1186/2041-7136-2-1

Ort, D. R., \& Ainsworth, E. (2012). Focus on Climate Change. Plant Physiology, 160 (4), 1675-1676. doi: 10.1104/pp.112.900450

Pratt, D. J., \& Gwynne, M. D. (1977). Rangeland management and ecology in East Africa : Hodder and Stoughton.

Rahman, A., Duncan, A. J., Miller, D. W., Clemens, J., Frutos, P., Gordon, I. J., . . . Wright, I. A. (2008). Livestock feed resources, production and management in the agro-pastoral system of the Hindu Kush-Karakoram-Himalayan region of Pakistan: The effect of accessibility. Agricultural systems, 96 (1-3), 26-36. doi: $10.1016 /$ j.agsy.2007.05.003

Reid, R. S., Kruska, R. L., Muthui, N., Taye, A., Wotton, S., Wilson, C. J., \& Mulatu, W. (2000). Land-use and land-cover dynamics in response to changes in climatic, biological and socio-political forces: the case of southwestern Ethiopia.Landscape Ecology, 15 (4), 339-355.

Rotherham, I. D. (2013). Trees, forested landscapes and grazing animals: a European perspective on woodlands and grazed treescapes: Routledge.

Rust, J., \& Rust, T. (2013). Climate change and livestock production: A review with emphasis on Africa.South African Journal of Animal Science, 43 (3), 255-267. doi: 10.4314/sajas.v43i3.3 
Smit, G. (2004). An approach to tree thinning to structure southern African savannas for long-term restoration from bush encroachment. Journal of Environmental Management, 71 (2), 179-191. doi: 10.1016/j.jenvman.2004.02.005

Timberlake, J., \& Reddy, S. J. (1986). Potential pasture productivity and livestock carrying capacity over Mozambique Serie Terra e Agua. Instituto Nacional de Investigacao Agronomica, Maputo (Vol. 49, pp. 28). Maputo, Mozambique: ISRIC - World Soil Information, as ICSU World Data Centre for Soils.

Tolera, A., Yami, A., \& Alemu, D. (Eds.). (2012). Livestock feed resources in Ethiopia: challenges, opportunities and the need for transformation. Addis Ababa, Ethiopia: Ethiopian Animal Feeds Industry Association.

USEPA. (2016). Climate impacts on agriculture and food supply (Vol. https://www.epa.gov/): United States Environmental Protection Agency.

Valtorta, S. E. (2002). Animal production in a changing climate: impacts and mitigation. 1-12.

Vetter, S. (2004). Rangelands at Equilibrium and Non-equilibrium. Recent Developments in the Debate around Rangeland Ecology and Management .

Virmani, S., Sahrawat, K., \& Burford, J. (1982). Physical and chemical properties of Vertisols and their management.

Warne, R. W., Pershall, A. D., \& Wolf, B. O. (2010). Linking precipitation and C3-C4 plant production to resource dynamics in higher-trophic-level consumers. Ecology, 91 (6), 1628-1638. doi: 10.1890/08-1471.1

Wickens, G. (1980). Alternative uses of browse species. In H. N. 1. Houerou (Ed.), Alternative uses of browse species. (pp. 155-182). Addis Ababa, Ethiopia International Livestock Centre for Africa (ILCA).

Wolde-Georgis, T., Aweke, D., \& Hagos, Y. (2000). The Case of Ethiopia: Reducing the impacts of Environmental Emergencies through Early Warning and ....

Wroe, R. (1988). Guide to range condition and stocking rates for Alberta grasslands, 1988 : Alberta Forestry, Lands and Wildlife, Public Lands Division.

Yamane, T. (1967). Statistics: An introductory analysis.

Yesuph, A. Y., \& Dagnew, A. B. (2019). Land use/cover spatiotemporal dynamics, driving forces and implications at the Beshillo catchment of the Blue Nile Basin, North Eastern Highlands of Ethiopia. Environmental Systems Research, 8 (1), 21. doi: 10.1186/s40068-019-0148-y

Žurovec, O., \& Vedeld, P. O. (2019). Rural Livelihoods and Climate Change Adaptation in Laggard Transitional Economies: A Case from Bosnia and Herzegovina. Sustainability, 11 (21), 6079. doi: $10.3390 /$ su11216079

Tables and Figures

Table 1. Description of Landsat

\begin{tabular}{llllll}
\hline Sensor Type & Path/row & No of Bands & Band combination & Spatial resolution & Acquisition date \\
\hline Landsat 5 () & $167 / 056$ & 7 & RGB 432 & $30 \mathrm{~m}$ & $30 / 01 / 1986$ \\
Landsat 5 () & $167 / 057$ & 7 & RGB 432 & $30 \mathrm{~m}$ & $23 / 01 / 1986$ \\
Landsat 5 () & $167 / 056$ & 7 & RGB 432 & $30 \mathrm{~m}$ & $7 / 01 / 1995$ \\
Landsat 5 () & $167 / 057$ & 7 & RGB 432 & $30 \mathrm{~m}$ & $23 / 01 / 1995$ \\
Landsat 5 () & $167 / 056$ & 7 & RGB 432 & $30 \mathrm{~m}$ & $2 / 12 / 2010$ \\
Landsat 5 () & $167 / 057$ & 7 & RGB 432 & $30 \mathrm{~m}$ & $1 / 02 / 2010$ \\
Landsat 8 (OLI) & $167 / 056$ & 11 & RGB 543 & $30 \mathrm{~m}$ & $22 / 01 / 2018$ \\
Landsat 8 (OLI) & $167 / 057$ & 11 & RGB 543 & $30 \mathrm{~m}$ & $21 / 01 / 2018$ \\
\hline
\end{tabular}


Table 2. Land use/ land cover change analysis (1986-2018)

\begin{tabular}{lllllll}
\hline LULC type & Area in ha & Area in ha & Area in ha & Area in ha & Changes rate of land use/cover & Changes rate of land u \\
\hline & $\mathbf{1 9 8 6}$ & $\mathbf{1 9 9 5}$ & $\mathbf{2 0 1 0}$ & $\mathbf{2 0 1 8}$ & $\mathbf{1 9 9 5 - 1 9 8 6}$ & $\mathbf{2 0 1 0 - 1 9 9 5}$ \\
Bushland & 258,752 & 259,249 & 272,807 & $276,345^{* *}$ & 0.19 & 5.23 \\
Cropland & 28,018 & 53,895 & 78,902 & $108,520^{* *}$ & 92.36 & 46.40 \\
Forest & $100,457^{* *}$ & 100,417 & 70,217 & 58,364 & -0.04 & -30.07 \\
Grassland & $114,530^{* *}$ & 107,468 & 101,907 & 88,810 & -6.17 & -5.17 \\
Settlement & 122 & 1,328 & 1,650 & $1,913^{* *}$ & 988.52 & 24.25 \\
Woodland & $175,211^{* *}$ & 154,733 & 151,607 & 143,138 & -11.69 & -2.02 \\
Total & 677,090 & 677,090 & 677,090 & 677,090 & & \\
\hline
\end{tabular}

LULC is Land use /land cover change; ** indicates significantly higher at 0.01

Table 3. The maximum limit of livestock number that can graze/browse for one year

\begin{tabular}{llllll}
\hline Pasture type & Livestock CC (TLU) & Livestock CC (TLU) & Livestock CC (TLU) & Livestock CC (TLU) & Changes rat \\
\hline & $\mathbf{1 9 8 6}$ & $\mathbf{1 9 8 7 - 1 9 9 5}$ & $\mathbf{1 9 9 6 - 2 0 1 0}$ & $\mathbf{2 0 1 1 - 2 0 1 8}$ & $\mathbf{1 9 9 5 - 1 9 8 6}$ \\
Grassland & $158,482.65$ & $118,968.40$ & $84,609.23$ & $55,180.53$ & -24.93 \\
Bushland & $205,158.73$ & $145,801.09$ & $173,603.78$ & $102,795.68$ & -28.93 \\
Woodland & $138,920.92$ & $87,021.51$ & $128,635.74$ & $53,244.92$ & -37.36 \\
Forest & $79,650.13$ & $56,474.31$ & $59,577.83$ & $21,710.42$ & -29.10 \\
Total & $582,212.43$ & $408,265.31$ & $446,426.57$ & $232,931.56$ & -29.88 \\
\hline
\end{tabular}

Where CC $=$ carrying capacity; TLU $=$ Tropical Livestock Unit

Table 4. Carrying capacity of the rangeland in the study areas

\begin{tabular}{lllllllll}
\hline Vegetation cover & $\mathbf{1 9 8 6}$ & $\mathbf{1 9 8 6}$ & $\mathbf{1 9 8 7 - 1 9 9 5}$ & $\mathbf{1 9 8 7 - 1 9 9 5}$ & $\mathbf{1 9 9 6 - 2 0 1 0}$ & $\mathbf{1 9 9 6 - 2 0 1 0}$ & $\mathbf{2 0 1 1 - 2 0 1 8}$ & $\mathbf{2 0 1 1 - 2}$ \\
\hline & TLU/ha & ha/TLU & TLU/ha & ha/TLU & TLU/ha & ha/TLU & TLU/ha & ha/TL \\
Grass & 1.38 & 0.72 & 1.11 & 0.90 & 0.83 & 1.20 & 0.62 & 1.61 \\
Bush/shrub & 0.79 & 1.26 & 0.56 & 1.78 & 0.64 & 1.57 & 0.37 & 2.69 \\
Woody and Forest & 1.58 & 2.52 & 1.12 & 3.56 & 1.7 & 2.36 & 0.74 & 5.38 \\
Total & 3.76 & 4.51 & 2.79 & 6.24 & 3.16 & 5.13 & 1.74 & 9.67 \\
\hline
\end{tabular}

Where; TLU $=$ Tropical Livestock Unit; ha $=$ hectare

Table 5. A stocking rate of rangeland in (TLU/ha)

\begin{tabular}{|c|c|c|c|c|c|c|}
\hline Year & Grassland & Grassland & Bushland & Bushland & Woody and Forest & Woody and Forest \\
\hline & G_SR & O_SR & B_SR & O_SR & B_SR & O_SR \\
\hline 1986 & $5 . \overline{12}$ & $5 . \overline{99}$ & $0 . \overline{7} \overline{7}$ & $5 . \overline{3}$ & $3 . \overline{12}$ & 21.49 \\
\hline $1987-95$ & 5.94 & 9.11 & 2.63 & 7.56 & 11.2 & 32.17 \\
\hline 1996-2010 & 7.36 & 17.1 & 7.28 & 12.78 & 41.38 & 72.63 \\
\hline $2011-18$ & 11.79 & 26.38 & 9.38 & 16.95 & 62.51 & 113.01 \\
\hline Change rate & Change rate & & & & & \\
\hline $1995-86$ & 16.02 & 52.09 & 241.56 & 42.64 & 258.97 & 49.70 \\
\hline 2010-1995 & 23.91 & 87.71 & 176.81 & 69.05 & 269.46 & 125.77 \\
\hline
\end{tabular}




\begin{tabular}{llllllll}
\hline Year & Grassland & Grassland & Bushland & Bushland & Woody and Forest & Woody and Forest & . \\
\hline $2018-10$ & 60.19 & 54.27 & 28.85 & 32.63 & 51.06 & 55.60 & 425.87 \\
$2018-1986$ & 130.27 & 340.40 & 1118.18 & 219.81 & 1903.53 & 13.31 & \\
Changes/ year & 4.07 & 10.64 & 34.94 & 6.87 & 59.49 & & \\
\hline
\end{tabular}

$G_{-} S R=$ Grazer Stocking rate (considering the sum of cattle and sheep TLU); B_SR = Browser Stocking rate (considering camel and goat TLU); $O_{-} S R=$ Overall stocking rate (considering the sum TLU of all livestock species).

Table 6. Test of using Mann-kendall test statistics

\begin{tabular}{lll}
\hline Variable & tau & p-value \\
\hline Mean annual temperature & $0.304^{* *}$ & 0.00 \\
Annual rainfall & -0.00361 & 0.92 \\
Cattle & $0.831^{* *}$ & 0.00 \\
Sheep & $-0.126^{* *}$ & 0.00 \\
Goat & $0.397^{* *}$ & 0.00 \\
Camel & $1.00^{* *}$ & 0.00 \\
\hline
\end{tabular}

** indicates statistical significance at $1 \%$ level. Data source: NMA, 2018

Table 7. Perception of pastoral and agro-pastoral community on feed and water trends

\begin{tabular}{lllll}
\hline Parameter & Decreasing & No_change & Not sure & Pr $>$ ChiSq \\
\hline Feed availability & $147(74.2)$ & $35(17.7)$ & $16(8.1)$ & $<.0001$ \\
Feed quality & $129(65.2)$ & $38(19.2)$ & $31(15.7)$ & $<.0001$ \\
Water availability & $165(83.3)$ & $24(12.1)$ & $9(4.5)$ & $<.0001$ \\
\hline
\end{tabular}

Note: value in parenthesis indicates $\%$

Table 8. The relationship of temperature and rainfall pattern with rangeland feed productivity and quality

\begin{tabular}{lllll}
\hline Parameter & & Temperature pattern & Temperature pattern & Temperature patter \\
\hline \multirow{3}{*}{ Feed availability } & Pattern & Increasing & Decreasing & No change \\
& Decreasing & 75.6 & 75.0 & 66.7 \\
& No change & 18.3 & 25.0 & 13.3 \\
& Not sure & 6.1 & 0.0 & 20.0 \\
Feed quality & Pr $>X^{2}$ & $<.0001$ & 0.3173 & 0.0005 \\
& Decreasing & 64.6 & 75.0 & 66.7 \\
& No change & 21.3 & 25.0 & 6.7 \\
Adaptation to low-quality feed & Not sure & 14.0 & 0.0 & 26.7 \\
& Pr $>X^{2}$ & $<.0001$ & 0.3173 & 0.0002 \\
& Cattle & 12.2 & 50.0 & 16.7 \\
& Sheep & 8.5 & 25.0 & 6.7 \\
& Camel & 53.7 & 0.0 & 70.0 \\
& Goat & 25.6 & 25.0 & 6.7 \\
& Pr $>X^{2}$ & $<.0001$ & 1.00 & $<.0001$ \\
\hline
\end{tabular}


Source: Own survey data

Table 9. The probability of choosing livestock species in increasing pattern of temperature and declining rate of feed resources.

\begin{tabular}{|c|c|c|c|}
\hline Choosing livestock species & Camel & Sheep & Goat \\
\hline \multirow[t]{4}{*}{ Temperature } & $1.39^{*}$ & 0.14 & 0 \\
\hline & $1.61^{* *}$ & 0.36 & 0.22 \\
\hline & 0 & -1.25 & $-1.39^{* *}$ \\
\hline & 1.25 & 0 & -0.14 \\
\hline \multirow[t]{4}{*}{ Feed availability } & -0.18 & 0.86 & 0 \\
\hline & 0.25 & $1.29^{*}$ & 0.43 \\
\hline & 0 & 1.05 & 0.18 \\
\hline & -1.05 & 0 & -0.86 \\
\hline Adaptation of livestock species & Adaptation of livestock species & Adaptation of livestock species & Adapta \\
\hline \multirow[t]{4}{*}{ Temperature } & 0 & -0.22 & $-0.06^{*}$ \\
\hline & 0.22 & 0 & 0.15 \\
\hline & 0.06 & -0.15 & 0 \\
\hline & 0.81 & 0.59 & 0.75 \\
\hline \multirow[t]{4}{*}{ Feed availability } & 0 & 0.04 & -0.14 \\
\hline & -0.04 & 0 & -0.18 \\
\hline & 0.14 & 0.18 & 0 \\
\hline & 0.05 & 0.09 & -0.09 \\
\hline
\end{tabular}

Note: ${ }^{*}, * *=$ significant at $1 \%$ and $5 \%$ probability level, respectively

Source: survey data;

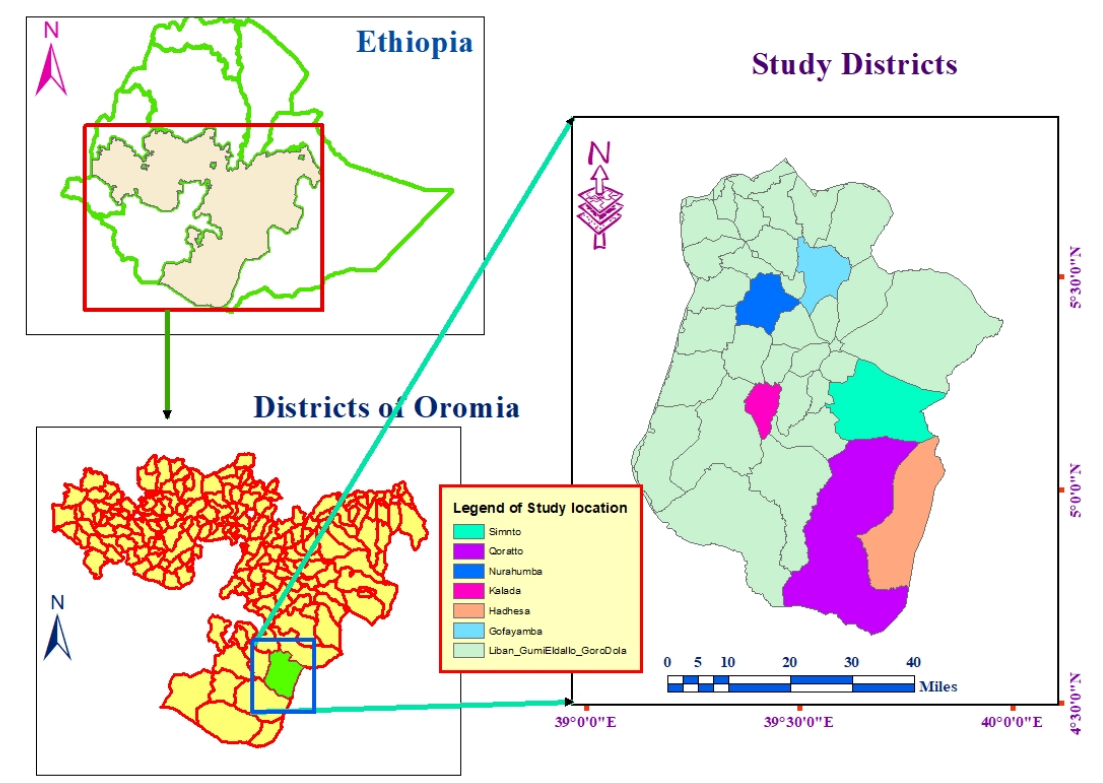

Figure 1. Location map of the study area 

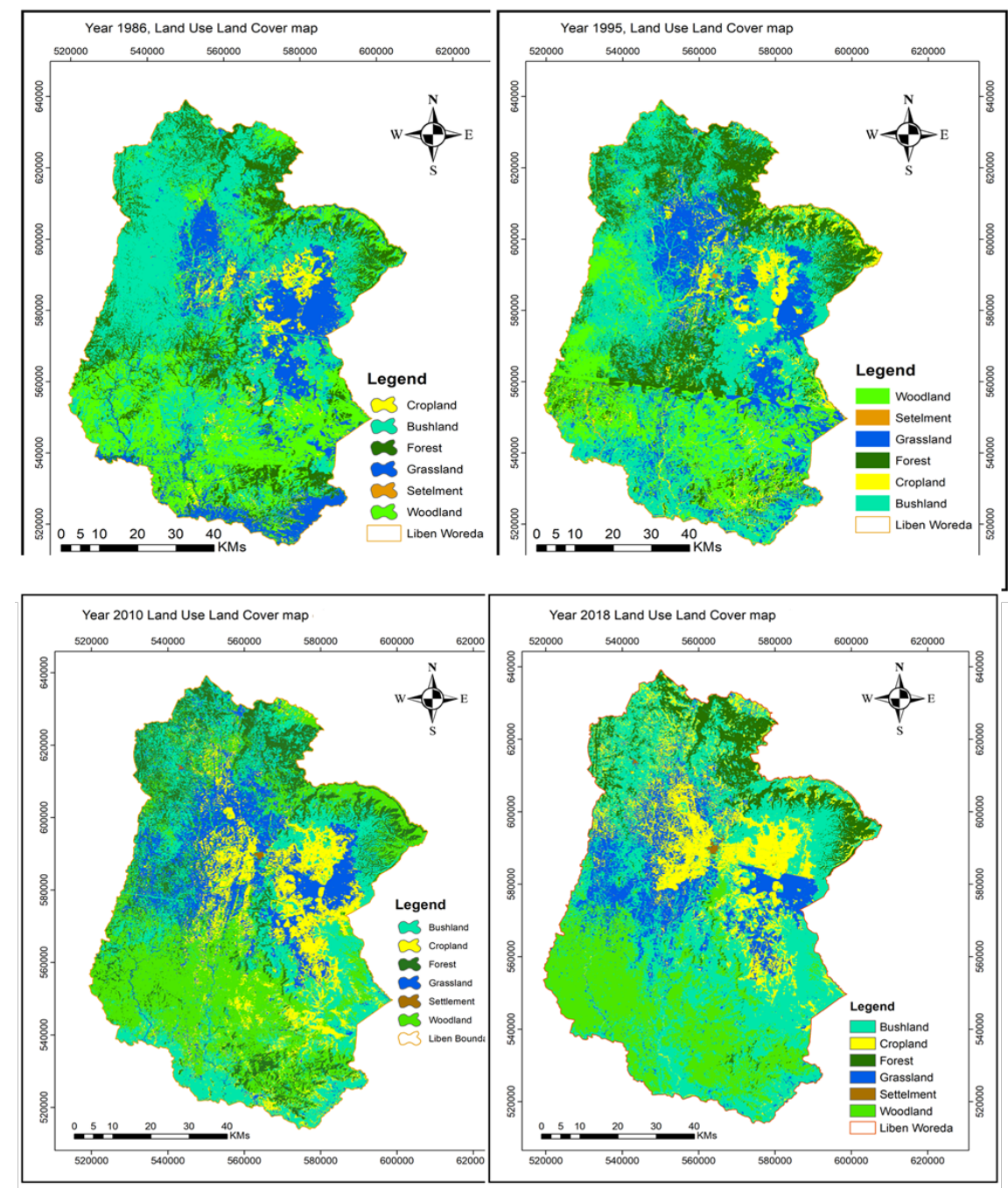

Figure 2. Land use/cover change analysis (1986-2018) 


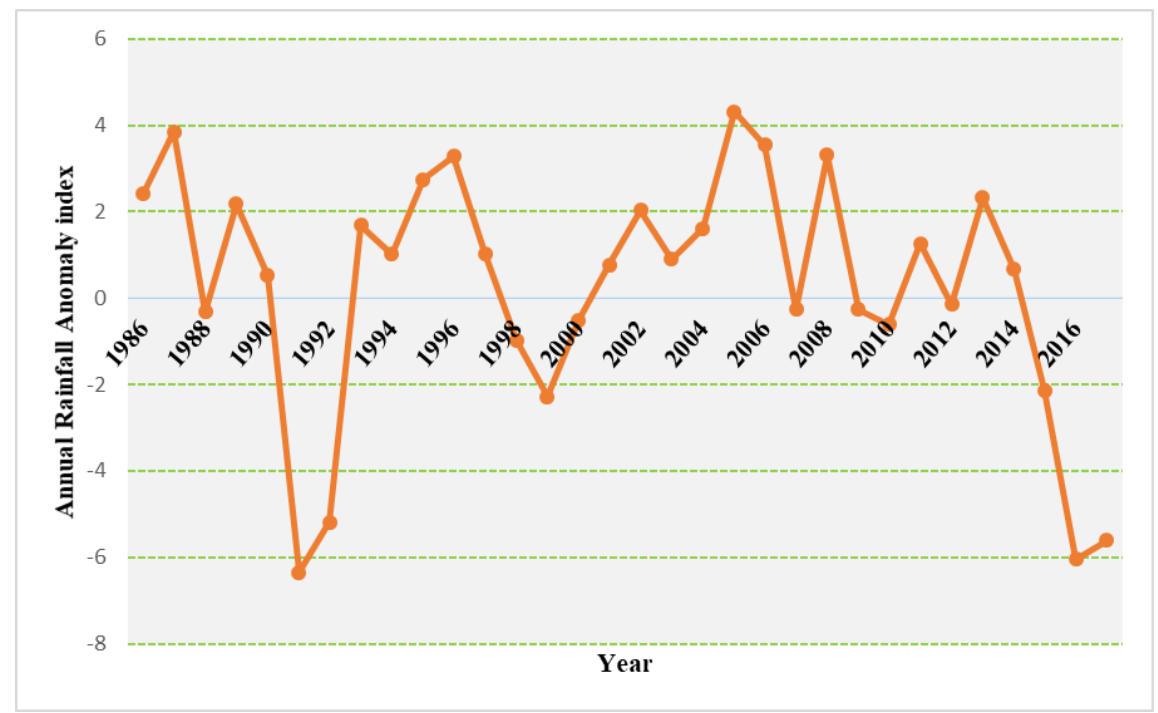

Figure 3. Rainfall anomaly index throughout the analysis period (1986-2018).

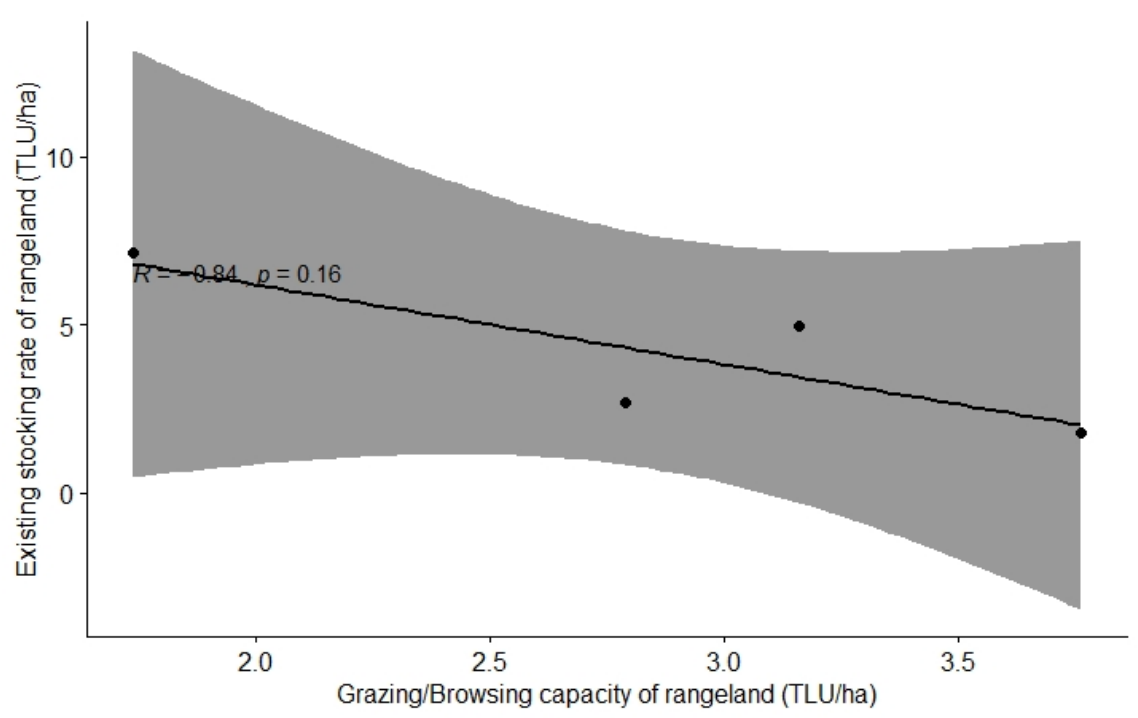

Figure 4. The relationships between carrying capacity and stocking rate throughout the study period (19862018) 


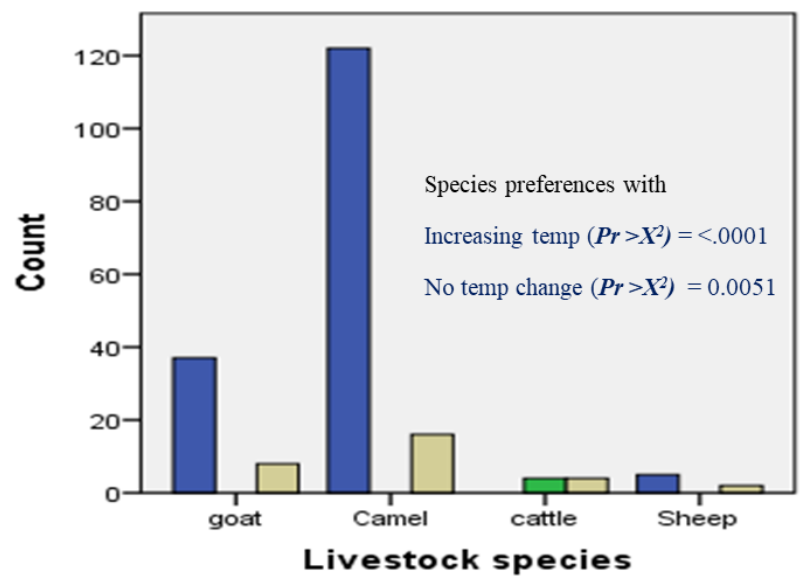

Temperature pattern

$\square$ increasing

$\square$ decreasing

$\square$ no_change

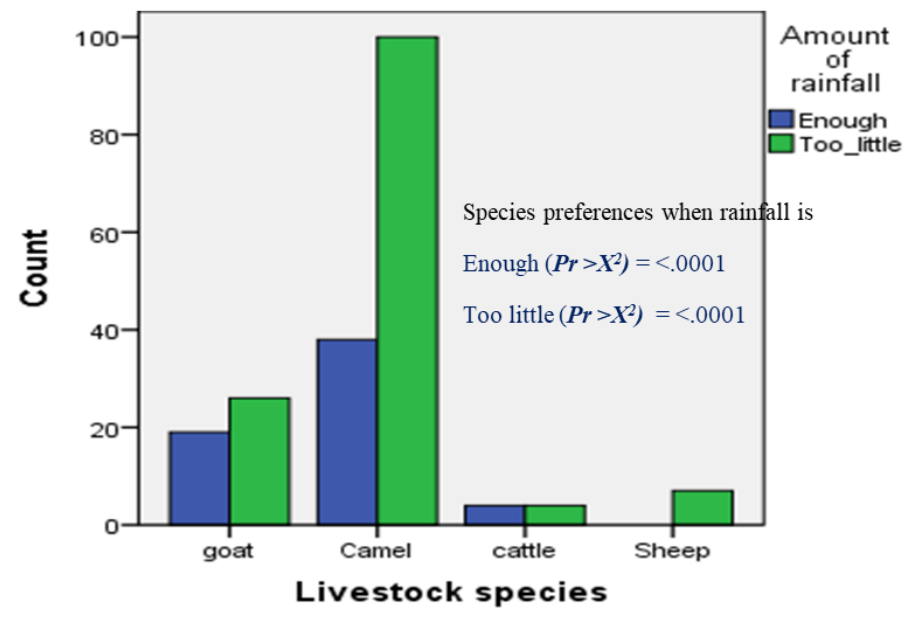

Figure 5. The association of temperature and rainfall with choosing livestock species

\section{Hosted file}

MatiwosFigures.pdf available at https://authorea.com/users/360371/articles/483936-land-usecover-change-analysis-and-its-implication-on-livestock-feed-resource-availabilities-insoutheastern-rangeland-of-ethiopia 